Research Article

\title{
Knowledge and attitude on HIV/AIDS among adolescent school children in urban Mysuru, Karnataka, India: a cross sectional study
}

\author{
Vijayageetha $M^{*}$, Narayanamurthy MR, Vidya G. S., Renuka M
}

Department of Community Medicine, JSS Medical College, Mysore, Karnataka, India

Received: 08 March 2016

Accepted: 06 April 2016

\section{*Correspondence:}

Dr. Vijayageetha M,

E-mail: drmvgeetha@gmail.com

Copyright: (c) the author(s), publisher and licensee Medip Academy. This is an open-access article distributed under the terms of the Creative Commons Attribution Non-Commercial License, which permits unrestricted non-commercial use, distribution, and reproduction in any medium, provided the original work is properly cited.

\begin{abstract}
Background: Adolescence is a stage of physiological, mental and social transformation which poses a threat for risky health behaviours. Inadequate knowledge, taboos regarding sex education, indulgence in risky behaviour lends the adolescents susceptible to AIDS (Acquired Immuno Deficiency Syndrome). Hence, this study was undertaken with the objective to assess the knowledge and attitude towards HIV/AIDS among Adolescent school children in urban Mysore and to describe the factors influencing the same.

Methods: This cross sectional study was conducted among schools and pre-university colleges. A simple random sampling technique was used to select the schools and pre-university college and two classes from each school were selected randomly and all adolescents in the class who were present on the day of the study were included. Information regarding their socio-demographic characteristics, knowledge and attitude regarding HIV/AIDS were obtained using a self-administered, pre-tested, semi-structured questionnaire. The children who were mentally disabled were excluded.

Results: Among the 374 adolesecents who participated, textbooks 275 (73.5\%) were the most common source of information about HIV/AIDS. Knowledge about modes of transmission was higher than about prevention and control and a majority had a positive attitude towards a relative, a friend, a fellow student and teacher whereas, around $50 \%$ had a negative attitude towards a shopkeeper or a housekeeper affected with HIV (Human Immuno Deficiency Virus). Conclusions: Optimal utilization of mass media to deliver key messages and reinforcement using curriculum content would improve the knowledge about HIV and to bring down the discrimination of people living with HIV among adolescents. Life skill education with HIV awareness should be implemented in schools.
\end{abstract}

Keywords: Knowledge, Attitude, HIV/AIDS, Adolescents

\section{INTRODUCTION}

Adolescence is one of the most rapid phases of development, constitute 10-19 years of age ${ }^{1}$ and contribute to $19.6 \%$ of the Indian population. ${ }^{2}$ It is one of the most crucial stages in the life of an individual, metamorphosing from being a child into becoming responsible adults. It establishes a strong foundation for adulthood, which propels one to move in the right direction with a right influence and a lack thereof resulting in disastrous consequences, generating an economically productive but a morally precarious population. Adolescence, a stage of physiological, mental and social transformation which accompanies inquisitiveness, impulsiveness and experimentation, makes them prone for risky health behaviours. These behaviours make them vulnerable to diseases especially sexually transmitted diseases such as AIDS.

AIDS caused by HIV stands as a threat to entire mankind stigmatizing those affected and petrifies the rest and has rightly been called a social disease. Although, a vast 
amount of accessible information is available about the disease and a significant progress made in the past two decades on prevention, control and cure, the extent of utilization still remains a challenge to be explored. A report released by UNICEF and UNAIDS revealed, the number of adolescents aged 10-19 officially estimated to be living with HIV in Asia and the Pacific has increased over the past decade, reaching 220,000 in 2014. Despite the reduction in AIDS-related deaths among adults, those 10-19 year olds in the region increased by 110 per cent between 2005 and 2014, which is alarming. ${ }^{3}$

Inadequate knowledge of development, lack of correct health information, the taboos associated with sex education at homes and schools, indulgence in risky behaviours and a lack of access to adequate reproductive health services further lends the adolescents susceptible to AIDS. Once the epidemic sets out in this age group, it is tougher to trace and treat. AIDS largely relies on prevention and the right information at the right time is essential to bring about a behavioural change when the population is most receptive. An adequate knowledge is imperative to prevent the increasing burden. Hence, the present study was undertaken to assess the knowledge about HIV and attitude towards people living with HIV among the study population.

Objectives of the study are to assess the knowledge and attitude towards HIV/AIDS among adolescents in Mysuru city and to describe the factors influencing the knowledge and attitude among the adolescents.

\section{METHODS}

This cross sectional study was conducted between October and December 2013, in 19 High schools and PreUniversity Colleges coming under JSS Mahavidyapeetha. The students belonging to classes 9, 10 and 11(13-17 years of age) in the selected institutions were the study participants. The sample size was calculated using the formula $\mathrm{n}=\mathrm{z} \alpha^{2} \mathrm{pq} / \mathrm{l}^{2}$, taking $\mathrm{p}$ as $60 \%$, from the findings of a previous study, ${ }^{4}$ an absolute allowable error of $5 \%$ was taken at $95 \%$ confidence interval and the level of significance kept at less than 0.05 and a sample size of 368 was obtained, rounded to 375 and finally a total 374 students participated in the study.

Permission was obtained from the concerned head of the institution before commencing the study. The schools and PU College were selected by simple random sampling technique. Two classes from each school were selected randomly and all the adolescents in the class who were present on the day of the study were included after explaining the purpose of the study. Informed consent/assent was taken from those who were willing to take part in the study and confidentiality was maintained. Information regarding their socio-demographic characteristics, knowledge and attitude regarding HIV/AIDS were obtained using a self-administered, pretested, semi-structured questionnaire containing questions and given 15 minutes time to complete the questionnaire and collected at the end of the given time. The children who were mentally disabled were excluded. Ethical clearance was obtained from Institutional Ethical Committee, JSS Medical College, Mysore.

The data was analysed using SPSS version 22.0 and descriptive statistics represented as frequencies and proportions and Chi-square test was used to test the significance at $95 \%$ confidence interval and $\mathrm{p}$ value of less than 0.05 was considered to be statistically significant.

\section{RESULTS}

Table 1: Socio - demographic characteristics of the study subjects.

\begin{tabular}{|lll|}
\hline Variable & Frequency & Proportion \\
\hline Age in years & & \\
\hline$<16$ & 184 & 49.2 \\
\hline $16-18$ & 190 & 50.8 \\
\hline Sex & & \\
\hline Male & 96 & 25.7 \\
\hline Female & 278 & 74.3 \\
\hline Religion & \\
\hline Hindu & 347 & 92.8 \\
\hline Muslim & 07 & 1.9 \\
\hline Christian & 15 & 4.0 \\
\hline Jains & 05 & 1.3 \\
\hline Locality of residence & \\
\hline Urban & 258 & 69.0 \\
\hline Rural & 116 & 31.0 \\
\hline Parent's literacy status (atleast one)* & \\
\hline Uneducated & 38 & 10.2 \\
\hline Educated & 336 & 89.8 \\
\hline
\end{tabular}

*Literacy status of atleast one of the parent.

The study included 374 adolesecents among whom $25.7 \%$ were male and $74.3 \%$ female as seen in Table 1 .

Table 1, summarizes the adolesecents were fairly equal in number in the age categories, less than 16 years, i.e. 184 (49.2) and 16 to 18 years, i.e. 190 (50.8). The number of female children, i.e. 278 (74.3) outnumbered the males, i.e. 96 (25.7) in the study population. Most of them, 347 (92.8) were hindu by religion and residing at an urban locality, 258 (69.0) and the rest were students whose parents were in rural areas, but are currently residing at a relative's house or hostel for education purpose.

Table 2, shows the knowledge about the modes of transmission of HIV. It shows that a high proportion of children had adequate knowledge about the correct modes of transmission in all domains. However, 196 $(52.4 \%)$ have responded that HIV is transmitted by mosquitoes. 
Table 3, summarizes that less than $60 \%$ responded correctly with regard to vaccine against HIV, alcohol and risky behaviours increases risk of HIV, cure for HIV and about laws for discrimination against people living with HIV.

Table 2: Knowledge on modes of transmission of HIV.

\begin{tabular}{|lll|}
\hline $\begin{array}{l}\text { Knowledge of transmission } \\
\text { by/ through/ from }\end{array}$ & Frequency & Percentage \\
\hline $\begin{array}{ll}\text { Misconceptions } \\
\text { Shaking hands }\end{array}$ & 24 & 6.4 \\
\hline Sharing plates & 86 & 23.0 \\
\hline Sharing clothes & 50 & 13.4 \\
\hline Sharing the same toilet & 108 & 29.9 \\
\hline Through mosquito bite & 196 & 52.4 \\
\hline Breath & 98 & 26.2 \\
\hline Kissing & 139 & 38.2 \\
\hline Modes of transmission & & \\
\hline Blood transfusion & 334 & 89.3 \\
\hline Sharing a needle or a syringe & 358 & 95.7 \\
\hline Mother to child & 331 & 88.5 \\
\hline Sexual intercourse & 335 & 89.6 \\
\hline Breast milk & 311 & 83.2 \\
\hline
\end{tabular}

Table 3: Knowledge of prevention and control of HIV.

\begin{tabular}{|llc|}
\hline $\begin{array}{l}\text { Knowledge on prevention } \\
\text { and control regarding }\end{array}$ & Frequency & Percentage \\
\hline $\begin{array}{l}\text { Absence of a vaccine against } \\
\text { HIV }\end{array}$ & 159 & 42.5 \\
\hline Prevention by blood testing & 319 & 85.3 \\
\hline $\begin{array}{l}\text { Alcohol and other drugs } \\
\text { increases risky behavior } \\
\text { associated with HIV }\end{array}$ & 218 & 58.3 \\
\hline $\begin{array}{l}\text { Prevention by remaining } \\
\text { faithful to a single partner }\end{array}$ & 286 & 76.5 \\
\hline $\begin{array}{l}\text { Prevention by condom usage } \\
\text { during sexual contact }\end{array}$ & 310 & 82.9 \\
\hline $\begin{array}{l}\text { Awareness about a separate } \\
\text { testing facility }\end{array}$ & 256 & 68.4 \\
\hline $\begin{array}{l}\text { Awareness of treatment for } \\
\text { HIV }\end{array}$ & 270 & 72.2 \\
\hline Absence of cure for HIV & 205 & 54.8 \\
\hline $\begin{array}{l}\text { Discrimination against } \\
\text { people living with HIV } \\
\text { punishable by law }\end{array}$ & 193 & 51.6 \\
\hline
\end{tabular}

Table 4 shows, factors such as age and literacy status of atleast one of the parents is statistically significant.

Table 5 shows, all other factors except sex of the participant were statistically not significant.

The median scores for knowledge and attitude regarding HIV/AIDS was calculated, based on which the knowledge domain was divided into two categories.
Those with a median score less than 16 were considered to have a poor knowledge and those with scores above 16 were considered good knowledge. Similarly, attitude was also divided into two categories and those with a median score less than 9 were considered as positive attitude and more than 9 as negative attitude.

Table 4: Association of socio-demographic characteristics with knowledge of HIV/AIDS.

\begin{tabular}{|c|c|c|c|c|}
\hline \multirow{2}{*}{ Factors } & \multirow{2}{*}{ Category } & \multicolumn{2}{|c|}{ Knowledge } & \multirow{2}{*}{$\begin{array}{l}p \\
\text { value }\end{array}$} \\
\hline & & Poor & Good & \\
\hline \multirow[t]{2}{*}{$\begin{array}{l}\text { Age in } \\
\text { years }\end{array}$} & $\begin{array}{l}\text { Less than } \\
16\end{array}$ & $100(57.5)$ & $84(42.0)$ & \multirow[t]{2}{*}{0.003} \\
\hline & $16-18$ & $74(42.5)$ & $116(58.0)$ & \\
\hline \multirow[t]{2}{*}{ Sex } & Male & $38(21.8)$ & $58(29.0)$ & \multirow[t]{2}{*}{0.114} \\
\hline & Female & $136(78.2)$ & $142(71.0)$ & \\
\hline \multirow[t]{2}{*}{ Religion } & Hindu & $158(90.8)$ & $189(94.5)$ & \multirow[t]{2}{*}{0.168} \\
\hline & Others & $16(9.2)$ & $11(5.5)$ & \\
\hline \multirow[t]{2}{*}{ Locality } & Rural & $48(27.6)$ & $68(34.0)$ & \multirow[t]{2}{*}{0.181} \\
\hline & Urban & $126(72.4)$ & $132(66.0)$ & \\
\hline \multirow{2}{*}{$\begin{array}{l}\text { Literacy } \\
\text { status }\end{array}$} & Illiterate & $11(6.3)$ & $27(13.5)$ & \multirow[t]{2}{*}{0.022} \\
\hline & Literate & $163(93.7)$ & 173(86.5) & \\
\hline
\end{tabular}

Table 5: Association of socio-demographic characteristics with attitude towards HIV/AIDS.

\begin{tabular}{|lllll|}
\hline Factors & Category & $\begin{array}{l}\text { Attitude } \\
\text { Positive }\end{array}$ & Negative & $\begin{array}{l}\text { p } \\
\text { value }\end{array}$ \\
\hline \multirow{2}{*}{$\begin{array}{l}\text { Age in } \\
\text { years }\end{array}$} & $\begin{array}{l}\text { Less than } \\
16\end{array}$ & $129(50.0)$ & $55(47.4)$ & 0.644 \\
& $16-18$ & $129(50.0)$ & $61(52.6)$ & \\
\cline { 2 - 4 } Sex & Male & $54(20.9)$ & $42(36.2)$ & \multirow{2}{*}{0.002} \\
\cline { 2 - 4 } & Female & $204(79.1)$ & $74(63.8)$ & \\
\hline Religion & Hindu & $238(92.2)$ & $109(94.0)$ & \multirow{2}{*}{0.553} \\
& Others & $20(7.8)$ & $7(6.0)$ & \\
\hline Locality & Rural & $81(31.4)$ & $35(30.2)$ & \multirow{2}{*}{0.813} \\
\cline { 2 - 4 } & Urban & $177(68.6)$ & $81(69.8)$ & \\
\hline $\begin{array}{l}\text { Parents } \\
\text { education }\end{array}$ & Illiterate & $22(8.5)$ & $16(13.8)$ & 0.119 \\
\cline { 2 - 4 } & Literate & $236(91.5)$ & $100(86.2)$ & \\
\hline
\end{tabular}

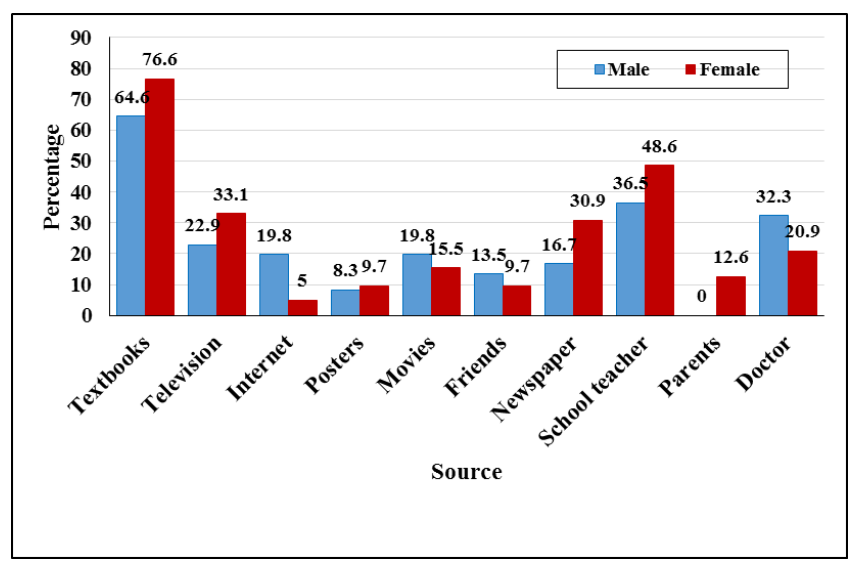

Figure 1: Distribution of study participants according to the source of information. 
Table 6: Association of knowledge characteristics with attitude among the study participants.

\begin{tabular}{|lll|l}
\hline Knowledge & $\begin{array}{l}\text { Attitude } \\
\text { Positive }\end{array}$ & Negative & P value \\
\hline Poor & $105(40.7)$ & $69(59.5)$ & \\
\cline { 1 - 2 } Good & $153(59.3)$ & $47(40.5)$ & \multirow{2}{*}{0.001} \\
\hline Total & 258 & 116 & \\
\hline
\end{tabular}

*Numbers in parenthesis indicate percentages.

Table 6 shows, the knowledge of the adolescent children with attitude was found statistically significant.

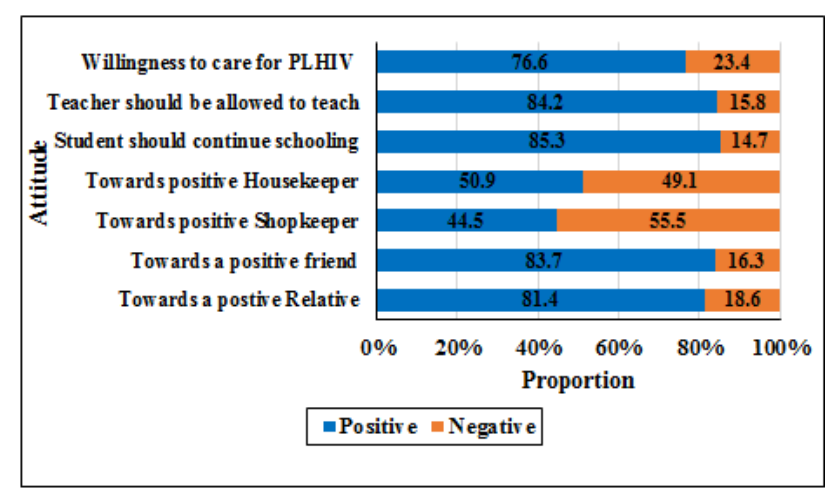

Figure 2: Distribution of adolescents based on attitude towards PLHIV.

\section{DISCUSSION}

The present study was undertaken to explore the levels of knowledge about HIV/AIDS and attitude towards PLHIV among the vulnerable adolescent population.

It was observed that textbooks $275(73.5 \%)$ were the most common source of knowledge, followed by information gathered from school teacher 170 (45.4) and television 114 (30.5). This can be attributed to the mandatory inclusion of HIV in school curriculum and an active particpication of teachers in imparting such valuable knowledge. Similar findings were reported by Sphiwe et $\mathrm{al}^{5}$ for the knowledge of HIV/ AIDS attributed to the life orientation curriculum in Africa. In contrast studies by Pankaj Kumar et $\mathrm{al}^{6}$ and Yazdi et $\mathrm{al}^{7}$ independently revealed that television was the most common source of information while teachers contributed for a smaller proportion in the first study, teachers (66\%) were pointed out as the next best source of information in Iran. However, parents contributed only to a very meagre amount which might be due to stigma in adults and a sense of discomfort among adolescents to discuss about sexually transmitted diseases which are considered a taboo in our social context.

The present study revealed that a high proportion of children had a knowledge about the correct modes of transmission of HIV, such as by blood transfusion $(89.3 \%)$, sharing needles $(95.7 \%)$, sexual transmission $(89.6 \%)$ and mother to child transmission (88.5\%) which can be attributed to the curricular inclusion of information on AIDS in the textbooks. This was in contrast to the observations made by $\mathrm{P}$ Lal et $\mathrm{al}^{8}$ and Chatterjee et $\mathrm{al}^{8}$ which showed a poor knowledge of transmission. The difference may be due to the different periods of study. A low proportion of misconceptions about transmission of HIV through sharing toilets, sharing plates, etc was observed, however, more than a half of them had misconceived that HIV is transmitted by mosquitoes $(53.4 \%)$ which was similar to the findings of Prathiba Gupta et al. ${ }^{10}$

Knowledge on prevention and control of HIV revealed that less than $60 \%$ responded correctly with regard to absence of an available vaccine against HIV, alcohol and risky behaviours increases risk of HIV, presence of a cure for HIV and about implementation of laws for discrimination against people living with HIV in this study, which were similar to the findings of Pankaj Kumar et $\mathrm{al}^{5}$ and Jaiswal et $\mathrm{al}^{11}$ which shows that correct knowledge regarding availability of vaccine for prevention of pretest were $28(27.45 \%)$ and $46.2 \%$ respectively. The misconceptions are caused due to a gap in knowledge. Overall, the findings are similar to a study done in Laos which states that though knowledge of transmission is good, misconceptions still persist. ${ }^{12}$ This reveals that knowledge about modes of transmission was higher than about prevention and control, which are more openly discussed through influencers and mass media than regarding the latter.

In the attitude domain, a mixed response was observed with majority having a positive attitude towards a relative, a friend, a fellow student and teacher whereas, around $50 \%$ had a negative attitude towards a shopkeeper or Housekeeper affected with HIV. Similar findings were observed in studies done at Laos, Ghana, Turkey and China. ${ }^{13-15}$ This might be owing to the closeness of relationship with the affected individual, which compels them to look beyond discrimination. Majority of them were willing to care for PLHIV but showed a hostile attitude towards a shopkeeper or a housekeeper for fear of contracting the disease. Measures to address stigma have to be kept in mind during successful planning and implementation of strategies. In a study done in Kolkata, $45.8 \%$ of girls and $38.8 \%$ of boys were willing to care for PLHIV $^{6}$ in contrast to our findings.

The limitations are although adolescents also include ages from 10 to 12 , they could not be included in the study due to cultural barriers. The out of school adolescents could not be addressed due to time and resource constraints.

\section{CONCLUSION}

To conclude, optimal utilization of mass media to deliver key messages and reinforcement using curriculum content would improve the knowledge about HIV and to bring down the discrimination of PLHIV. It is imperative 
to facilitate a one to one interaction with parents and teachers taking an active role with their adolescents to promote risk free healthy behaviour. Life skill education with HIV awareness should be implemented in schools and adolescents queries should be addressed as required. The adolescent's had a positive attitude towards friends and relatives affected with HIV whereas majority had a negative attitude towards shop-keeper and housekeeper affected with HIV which require targeted interventions.

\section{ACKNOWLEDGEMENTS}

Authors would like to thanks JSS Mahavidya Peetha for permitting to conduct the study, the school authorities for their support and co-operation and all adolescent school children for participating in the study.

\section{Funding: No funding sources}

Conflict of interest: None declared

Ethical approval: The study was approved by the Institutional Ethics Committee

\section{REFERENCES}

1. Maternal, newborn, child and adolescent health fact sheet. Geneva: World Health Organization; 2016. Available at: http://www.who.int/ maternal_child_adolescent/ topics/ adolescence/ development/en/ (Accessed on $2^{\text {nd }}$ March 2016).

2. C Chandramouli, Registrar General \& Census Commissioner, India. Adolescents and youth in india highlights from Census 2011. Available at: http://www.censusindia.gov.in/2011-

documents/PPT_World_Population/Adolescents_an d_Youth_in_India_Highlights_from_Census_2011. pptx (Accessed on 2nd March 2015).

3. Adolescents under the radar in the asia-pacific aids response. Unicef East Asia and Pacific Regional Office. December 2015.

4. Yadav SB, Makwana NR, Vadera BN, Dhaduk KM, Gandha KM. Awareness of HIV/AIDS among rural youth in India: a community based cross-sectional study. J Infect Dev Ctries. 2011;5(10):711-6.

5. Madiba S, Mokgatle MM. HIV and AIDS related knowledge and attitudes towards learners infected with HIV: survey among high school learners in Gauteng and North West provinces in South Africa. Peerj preprints. 2014;2:e693v1. Available at https://doi.org/10.7287/peerj.preprints.693v1. Accessed on 03.03.2016 at 7am.
6. Kumar P, Pore P, Patil U. Hiv/Aids related kap among high-school students of municipal corporation school in pune - an interventional study. NJCM. 2012;3(1):74-9.

7. Yazdi CA, Aschbacher K, Arvantaj A, Naser HM, Abdollahi E, Asadi A et al. Knowledge, attitudes and sources of information regarding HIV/AIDS in Iranian adolescents. AIDS Care. 2006;18(8):100410.

8. Lal P, Nath A, Badhan S, Ingle GK. A study of awareness about HIV/AIDS among senior secondary school children of delhi. Indian $\mathrm{J}$ Community Med. 2008;33(3):190-2.

9. Chatterjee C, Baur B, Ram R, Dhar G, Sandhukhan S, Dan A. A study on awareness of AIDS among school students and teachers of higher secondary schools in north Calcutta. Indian J Public Health. 2001;45(1):27-30.

10. Gupta P, Anjum F, Bhardwaj P, Srivastav JP, Zaidi ZH. Knowledge about HIV/AIDS among secondary school students. Najms. 2013;5(2):119-23.

11. Jaiswal S, Magar BS, Thakali K, Pradhan A, Gurubacharya DL. HIV/AIDS and STI related knowledge, attitude and practice among high school students in kathmandu valley. Kathmandu Univ Med J. 2005:3(1):69-75.

12. Thanavanh B, Rashid HO, Kasuya H, Sakamoto J. Knowledge, attitudes and practices regarding HIV/AIDS among male high school students in lao people's democratic republic. J Int AIDS Soc. 2013; 16(1):17387.

13. Sallar AM. Correlates of misperceptions in HIV knowledge and attitude towards people living with HIV/AIDS (PLHIV) among in-school and out-ofschool adolescents in Ghana. Afr Health Sci. 2009;9:82-91.

14. Koksal S, Namal N, Vehid S, Yurtsever E. Knowledge and attitude towards HIV/AIDS among Turkish students. Infect Dis J Pakistan. 2005;14:118-23.

15. Tan X, Pan J, Zhou D, Wang C, Xie C. HIV/AIDS knowledge, attitudes and behaviours assessment of Chinese students: a questionnaire study. Int J Environ Res Public Health. 2007;4:248-53.

Cite this article as: Vijayageetha M, Narayanamurthy MR, Vidya GS, Renuka M. Knowledge and attitude on HIV/AIDS among adolescent school children in urban Mysuru, Karnataka, India: a cross sectional study. Int J Community Med Public Health 2016;3:1224-8. 